\begin{abstract}
$178 \%$
Management for Production

"MANAGEMH TT Production", a pamphlet of 48 pages, price $2 s \sqrt{6} d$., has been issued by the British Institute Management to assist in raising productixity It is based on experience gained in many industres, and most of its suggestions are capable of infmediate application and of yielding early results. The ten chapters cover the measurement of work, process planning, the lay -out and organisation of shops, motion study, production planning and control, the maintenance of plant, morale, incentive payments, the control of quality, and costing and control. To all but the second chapter, slender reading lists are appended of somewhat variable quality, but possibly reasonably well adapted to the needs of those to whom this pamphlet is primarily addressed, namely, the small manufacturer and those who have hitherto given little thought to the systematic management of production.
\end{abstract}

\section{University of London}

THE folloying appointments in the University of London have been announced: Dr. F. W. Jane to the Unifersity chair of botany tenable at Royal Hollo ray College; Dr. C. F. Barwell to the University readership in bacteriology tenable at the London Hospital Medical College; Mr. R. B. Freeman to the University readership in taxonomy tenable at University College; Mr. J. J. Pritchard to the University readership in anatomy tenable at St. Mary's Hospital Medical School; Dr. H. C. Stewart to the University readership in pharmacology tenable at St. Mary's Hospital Medical School. All these appointments date from October 1, 1949.

The title of professor emeritus of anatomy in the University has been conferred on Prof. J. Kirk on his retirement from the $\mathrm{S}$. A. Courtauld chair of anatomy at Middlesex Hospital Medical School, which he has held since 1937.

The degree of D.Sc. has been conferred on D. H. R. Barton (Imperial College).

\section{University of Birmingham}

THE University of Birmingham has recently conferred the honorary degree of D.Sc. on Sir Alfred Egerton, Sir Hoyfard Florey, Dr. F. Peyton Rous and Sir Edmura Whittaker.

The following announcements have recently been made by the University. Appointments: F. R. N. Nabarro to be research fellow in metallurgy; Dr. H. McNanus to be lecturer in mathematical physics; R. H. Dalitz to be research fellow in mathematical physics ; Dr. A. B. L. Bezmak (formerly professor of physiology in the University of Budapest) to be lecturer in physiology; Dr. C. N. Iland to be lecturer in bacteriology. Resignation: Dr. M. Webb, lecturer in chemistry, on appointment as cytochemist at the Strangeways Research Laboratory, Cambridge.

The degree of D.Sc. has been conferred on N. J. L. Megson (chemistry).

\section{Colonial Service: Recent Appointments}

THe following appointments in the Colonial Service have been Announced. D. L. Downie, botanist, Uganda ; 1. B. Spence, agricultural officer, Kenya; H. W. Ball, geologist, Nyasaland; D. M. Corbett, veterizary officer, Tanganyika; D. J. Burdon, assigtant water engineer, geologist, Water Supply apd Irrigation Department, Cyprus; R. J. Garner, assistant meteorologist, Gold Coast; D. K. Jones, agricultural research officer, Cyprus; D. Moore, assistant conservator of forests, Trinidad; H. V. H.
July 30, 1949 Vol. 164

Morris, veterinary officer, Windward Islands; M. Greenwood (agricultural chemist, Nigeria), principal agricultural officer, Nigeria; R. J. M. Swynnerton (agricultural officer, Tanganyika), senior agricultural officer, Tanganyika; W. A. McD. Paterson (science master, Queens' Royal College, Trinidad), lecturer in general science (chemistry), Yaba Institute, Nigeria ; A. O. Thompson (engineer-geologist, Kenya), geologist, Kenya ; J. C. Bytheway (senior produce officer, Department of Marketing and Exports, Nigeria), principal produce officer, Department of Marketing and Exports, Nigeria; L. F. Edgerley (assistant conservator of forests, Mauritius), conservator of forests, Mauritius; R. A. Fitzjohn (sanitary superintendent, Medical Depariment, Nigeria), mosquito control officer, Nigeria.

The Night Sky in August

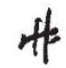

FuLt moon occurs on Aug. 8d. 19h. 33m., U.T., and new moon on Ayg exd. 03h. $59 \mathrm{~m}$. The following conjunct $1 s^{*}$ with té moon take place: Aug. 7d. 03h., Juditer $5^{\circ} \Omega N^{\prime}$; Aug. 21d. 05h., Mars $4^{\circ} \mathrm{S}$; Atag. 25d. A9\%., Mercury $3^{\circ}$ S.; Aug. 26d. 15h., Iens 0.4 . In addition to these conjunctions with ho moon, Mercury is in conjunction with Saturn on Adg. 13d. 14h., Mercury being $0 \cdot 6^{\circ} \mathrm{S}$. Mercury is an evening star, but sets too soon after the sun to be favourably observed throughout the month. Venus sets about an hour after the sun during August and can be seen in the western sky, stellar mag. $-3 \cdot 4$. Mars, in the constellation of Gemini, rises after 1 h. and is visible during the morning hours. Jupiter, in the constellation of Sagittarius, rises at $19 \mathrm{~h} .08 \mathrm{~m}$. $18 \mathrm{~h} .08 \mathrm{~m}$. and $17 \mathrm{~h} .02 \mathrm{~m}$. at the beginning, middle and end of the month, respectively, but is too low for favourable observation in higher northern latitudes. Saturn sets an hour after the sun on Aug. 1, and less than ten minutes after sunset at the end of the month, and is too close to the sun for observation. Only one star brighter than magnitude 6 is occulted during August, namely, 42 Libr., which disappears on Aug. 2d. 20h. 58.2m. The Perseid meteors are active during the month, attaining a maximum during Aug. 10-12.

\section{Announcements}

THE following announcements have recently been made by the University of Leeds. The title of reader in applied geology has been conferred upon Dr. H. C. Versey, senior lecturer in geology. Mr. W. L. J. Potts has been appointed lecturer in mining.

A Jornt committee of the Royal Society and the Armourers and Brasiers' Company has appointed W. K. Aoneycombe, of the University of Melbourne and the Cavendish Laboratory, Cambridge, to the Arfourers and Brasiers' Research Fellowship for two years from October 1, 1949. Mr. Honeycombe will work on the inhomogeneity of plastic deformation in metals, and the influence of these inhomogeneities on recrystallization and recovery.

ERrata. Article on "The Chemistry of the Heavy Elements' in Nature of June 25, p. 983: (a) in the referenge to the paper by Haissinsky and Bouissière (p. 983, col. 2, lower portion), the lower valence state of protactinium is believed to be $\mathrm{Pa}^{4+}$, not $\mathrm{Pa}^{3+}$, the reduced material being separable from lanthanum; (b) in the discussion of the paper by Bonet-Maury and Leport (p. 984, col. 1, bottom), Haissinsky's comments refer not to polonium, as stated, but to plutonium. 